\title{
Pengaturan Homoseksual dalam Hukum Pidana Indonesia
}

\author{
Kukuh Prima, Usman, Herry Liyus \\ Fakultas Hukum, Universitas Jambi \\ Author's Email Correspondence: kukuhprima0411@gmail.com
}

\section{ABSTRAK}

Artikel ini bertujuan untuk mengetahui dan menganalisis pengaturan homoseksual menurut hukum pidana Indonesia dan untuk mengetahui dan menganalisis kebijakan hukum pidana mengenai homoseksual. Metode Penelitian yang digunakan dalam penelitian ini adalah yuridis normatif. Hasil dari penelitian ini adalah Hubungan seksual sesama jenis yang dilakukan oleh homoseksual merupakan bagian dari tindak pidana menurut hukum pidana Indonesia, yaitu diatur di dalam ketentuan Pasal 292 KUHP, tetapi ketentuan tersebut terbatas hanya mengatur orang dewasa yang melakukan homoseksual dengan seorang anak di bawah umur saja. Perbuatan homoseksual antara pelaku dewasa perlu dijadikan sebagai tindak pidana di Indonesia dapat didasarkan pada tiga hal medasar, yakni dasar yuridis, teoritis, dan sosiologis. Saran Setelah penulis melakukan penelitian terhadap pengaturan homoseksual dalam hukum pidana indonesia, maka penulis ingin memberi saran yaitu bahwa perlu dilakukan kriminalisasi yang lebih luas terhadap hubungan homoseksual dari sekedar yang dilakukan oleh orang dewasa dengan anak dibawah umur diperluas juga terhadap hubungan seksual sesama jenis yang dilakukan oleh sesama orang dewasa.
\end{abstract}

Kata Kunci: Homoseksual; kebijakan hukum pidana; kriminalisasi.

\section{ARTICLE HISTORY}

Submission: 23-11-2020

Accepted: 2020-12-02

Publish: 2020-12-02

KEYWORDS: criminalization; criminal law policy; homosexuals.

\begin{abstract}
This article aims to investigate and analyze the regulation of homosexuals under Indonesian criminal law and to find out and analyze criminal law policies regarding homosexuals. The research method used in this research is normative juridical. The results of this study are same-sex sexual relations committed by homosexuals as part of a criminal act according to Indonesian criminal law, which is regulated in the provisions of Article 292 of the Criminal Code, but these provisions are limited to only regulating adults who commit homosexuality with a minor. Homosexual acts between adult perpetrators need to be made a crime in Indonesia and can be based on three basic things, namely juridical, theoretical and sociological grounds. Suggestion After the authors conducted research on the regulation of homosexuals in Indonesian criminal law, the authors would like to suggest that it is necessary to criminalize a wider range of homosexual relationships than just those committed by adults with minors and also to same-sex sexual relations committed by fellow adults.
\end{abstract}




\section{A. PENDAHULUAN}

Artikel ini membahas tentang perbuatan homoseksual yang aturannya dalam hukum pidana Indonesia masih terbatas mengatur antara orang dewasa terhadap anak sehingga pelaku homoseksual yang sesame telah dewasa tidak diancam oleh hukum pidana yang ada di indonesia

Sejak dahulu, isu homoseksual sering kali menjadi perdebatan di kalangan masyarakat Dunia. Permasalahan homoseksual di Indonesia terdapat pertentangan pendapat, antara pihak pro dan kontra. Mereka yang pro terhadap homoseksual menyatakan, bahwa negara dan masyarakat harus mengkampanyekan prinsip non diskriminasi antara lelaki, perempuan, trangender, pecinta lawan jenis heteroseksual maupun homoseksual. Pro homoseksual menjadikan hak asasi manusia sebagai dasar tuntutan mereka dengan menyatakan bahwa orientasi seksual adalah hak asasi manusia bagi mereka. Di Indonesia homoseksual adalah hal yang tergolong belum sepenuhnya dipahami. Banyaknya opini di media massa terkait dengan homoseksual ada beberapa pihak mendukung dan ada yang menolak keberadaan mereka bahkan banyak analisa yang menarik atas keberadaan homoseksual dari berbagai perspektif. Dalam Undang-Undang Nomor 39 Tahun 1999, HAM adalah seperangkat hak yang melekat pada diri manusia sebagai makhluk Tuhan Yang Maha Esa dan merupakan anugerahNYA yang wajib untuk dihormati, dijunjung tinggi dan dilindungi oleh Negara, hukum, pemerintah dan setiap orang demi kehormatan serta perlindungan harkat dan martabat seorang manusia. Kelompok homoseksual mengharapkan agar masyarakat dan Negara untuk mengakui keberadaan komunitas ini.

Dalam hukum Indonesia memandang HAM memiliki batasan, dimana batasanya adalah tidak boleh bertentangan dengan nilai-nilai agama, moral, keamanan dan ketertiban umum. Indonesia memang bukan Negara yang berdasarkan Agama namun Pancasila jelas menyatakan dalam sila pertamanya Ketuhanan Yang Maha Esa sehingga nilai-nilai agama menjadi penjaga sendi-sendi konstitusi dalam mewujudkan kehidupan demokratis bangsa Indonesia.

Dalam hukum pidana Indonesia khususnya KUHP ( Kitab Undang-undang Hukum Pidana) dalam hal status homoseksual ada pengaturannya di Indonesia, ada aturan pidana terkait hubungan sesama jenis yang terdapat dalam Pasal 292 KUHP yang menentukan: "Orang yang cukup umur, yang melakukan perbuatan cabul dengan orang lain sama kelamin, yang diketahui atau sepatutnya harus diduga, bahwa belum cukup umur, diancam dengan pidana penjara paling lama lima tahun"

R. Soesilo dalam bukunya "Kitab Undang-Undang Hukum Pidana (KUHP) serta Komentar-Komentarnya Lengkap Pasal Demi Pasal” menjelaskan bahwa:

1. Dewasa telah berumur 21 tahun atau belum berumur 21 tahun, akan tetapi sudah pernah kawin.

2. Jenis kelamin sama laki-laki dengan laki-laki atau perempuan dengan perempuan.

3. Tentang perbuatan cabul segala perbuatan yang melanggar kesusilaan (kesopanan) atau perbuatan yang keji, semuanya itu dalam lingkungan nafsu berahi kelamin, misalnya berciuman, meraba-raba anggota kemaluan, merabaraba buah dada, dan sebagainya. Dalam arti perbuatan cabul termasuk pula onani. 
4. Dua orang semua belum dewasa atau dua orang semua sudah dewasa bersama-sama melakukan perbuatan cabul, tidak dihukum menurut Pasal ini oleh karena yang diancam hukuman itu perbuatan cabul dari orang dewasa terhadap orang belum dewasa.

5. Supaya dapat dihukum menurut Pasal ini, maka orang dewasa itu harus mengetahui atau setidak-tidaknya patut dapat menyangka bahwa temannya berbuat cabul itu belum dewasa. ${ }^{1}$

Pihak-pihak yang kontra terhadap homoseksual, menilai bahwa homoseksual sebagai bentuk penyimpangan, dan tidak masuk dalam konsepsi HAM. Dalam hal ini, negara dan masyarakat harus berusaha semaksimal mungkin untuk melakukan upaya preventif terhadap gejala muncul dan berkembangnya homoseksual yang akan membahayakan generasi masa depan Indonesia. Oleh sebab itulah, posisi stategis pemerintah dalam hal ini sangat diperlukan untuk menangani polemik homoseksual secara langsung agar tak terjadi disintegrasi bangsa.

Situasi yang terjadi di Indonesia terkait fenomena homoseksual, tentunya tidak dapat dilepaskan dari gejolak fenomena homoseksual yang terjadi di tingkatan dunia internasional. Pada tahun 2011, Dewan Hak Asasi Manusia PBB mengeluarkan resolusi pertama tentang pengakuan atas hak-hak homoseksual, yang diikuti dengan laporan dari Komisi Hak Asasi Manusia PBB yang mendokumentasikan pelanggaran hak-hak dari orang-orang homoseksual, termasuk kejahatan kebencian, kriminalisasi homoseksualitas, dan diskriminasi. Menindaklanjuti laporan tersebut, Komisi Hak Asasi Manusia PBB mendesak semua negara untuk memberlakukan hukum yang melindungi hak-hak homoseksual. Dasar aturan yang digunakan oleh PBB adalah dalam perspektif Universal Declaration of Human Rights (Deklarasi Universal Hak-Hak Asasi Manusia).

Penerapan hukum hak asasi manusia internasional dipandu oleh prinsipprinsip universal dan nondiskriminasi yang tercantum dalam Pasal 1 dari Deklarasi Universal Hak-Hak Asasi Manusia menyatakan bahwa semua manusia dilahirkan bebas dan setara dalam martabat dan hak.dan setiap orang berhak untuk memperoleh hak dan kebebasannya tanpa diskriminasi apapun. ${ }^{2}$

Terdapat beberapa kasus penangkapan pelaku homoseks di Indonesia. Sebanyak 141 laki-laki digelandang polisi ke mapolres Jakarta utara dari dalam Ruko Inkopal dan Fitness Atlantis di kawasan Kelapa Gading, Jakarta Utara, minggu malam 21 Mei 2016.Para pria tersebut digrebek saat tengah asyik menggelar pesta seks sesama jenis alias homoseksual. Namun setelah melalui proses persidangan hakim menjatuhkan hukuman pada pelaku dengan menggunakan Undang-Undang Nomor 44 Tahun 2008 Tentang Pornografi. Kasus lainnya terjadi di Surabaya dimana tujuh gay yang melakukan pesta seks sesama jenis di Hotel Oval, jalan kedungdoro, Surabaya. hakim Pengadilan Negeri Surabaya juga menggunakan Undang-Undang Nomor 44 Tahun 2008 tentang Pornografi dalam vonis terhadap para pelaku. Tidak

\footnotetext{
$1 \quad$ R.Soesilo, Kitab Undang-Undang Hukum Pidana (KUHP) Serta Komentar- Komentarnya Lengkap Pasal Demi Pasal, Politeia, Bogor, 2010, hlm. 50.

2 Musdah Mulia, Mengupas seksualitas, Opus Press, Jakarta, 2015, hlm. 30.
} 
digunakannya Pasal 292 KUHP dalam beberapa kasus di atas dikarenakan Pasal ini digunakan apabila pelaku adalah dewasa dan korban belum cukup umur.

Direktur Media Saiful Mujani Research and Consulting (SMRC) Ade Armando mengatakan mayoritas penduduk Indonesia menolak lesbian, gay, biseksual, dan transgender. Hal ini diketahui dari survei SMRC yang dilakukan pada Maret 2016, September dan Desember 2017 dengan jumlah responden 1.220 orang. Margin of error survei ini sebesar lebih kurang 3,1 persen sampai 3,2 persen. Berdasarkan survei tersebut hampir seluruh penduduk Indonesia menilai LGBT adalah ancaman. Sebanyak 87,6 persen berpendapat demikian, sementara 10,8 persen berpandangan sebaliknya, dan sisanya tidak menjawab.

\section{B. METODE PENELITIAN}

Tipe penelitian yang penulis gunakan adalah penelitian hukum yuridis normatif, yaitu suatu penelitian ilmiah untuk menemukan kebenaran berdasarkan logika keilmuan hukum dari sisi normatif berdasarkan disiplin ilmiah dan cara-cara kerja ilmu hukum normatif, yaitu ilmu hukum yang objeknya adalah hukum itu sendiri. Mengkaji perbuatan catcalling dari perspektif hukum pidana yaitu dalam Kitab Undang-Undang Hukum Pidana. Kemudian dalam segi pembaharuan hukum harus mengkaji dari segi dasar kriminalisasi perbuatan homoseksual.

\section{PEMBAHASAN}

\section{Pengaturan Homoseksual Dalam Hukum Pidana Indonesia}

Pengaturan terhadap perbuatan yang digolongkan sebagai perbuatan pidana dalam hukum Indonesia diatur di dalam KUHP dan di beberapa undang-undang pidana khusus untuk perbuatan yang digolongkan sebagai perbuatan pidana setelah penetapan atau pengesahan KUHP di Indonesia pada tahun 1946. KUHP merupakan kitab yang dijadikan rujukan pertama ketika akan mencari hukuman yang akan dikenakan terhadap suatu perbuatan pidana, karena di dalam KUHP terdapat ketentuan-ketentuan umum dalam penegakan hukum pidana. Termasuk juga ketika membahas mengenai tindak pidana hubungan seksual sesama, sampai saat ini perilaku homoseksual masih belum diatur secara jelas dan menyeluruh di dalam KUHP. Pasal yang dijadikan dasar rujukan terhadap perbuatan seks menyimpang khususnya perbuatan cabul sesama jenis atau hubungan seksual sesama jenis selama ini hanyalah Pasal 292 KUHP yang menentukan: “Orang yang cukup umur, yang melakukan perbuatan cabul dengan orang lain sama kelamin, yang diketahui atau sepatutnya harus diduga, bahwa belum cukup umur, diancam dengan pidana penjara paling lama lima tahun"

R. Soesilo dalam bukunya Kitab Undang-Undang Hukum Pidana (KUHP) serta Komentar-Komentarnya Lengkap Pasal Demi Pasal menjelaskan bahwa:

1. Dewasa $=$ telah erumur 21 tahun atau belum berumur 21 tahun, akan tetapi sudah pernah kawin.

2. Jenis kelamin sama = laki-laki dengan laki-laki atau perempuan dengan perempuan. 
3. Tentang perbuatan cabul = segala perbuatan yang melanggar kesusilaan (kesopanan) atau perbuatan yang keji, semuanya itu dalam lingkungan nafsu berahi kelamin, misalnya berciuman, meraba-raba anggota kemaluan, meraba-raba buah dada, dan sebagainya. Dalam arti perbuatan cabul termasuk pula onani.

4. Dua orang semua belum dewasa atau dua orang semua sudah dewasa bersama-sama melakukan perbuatan cabul, tidak dihukum menurut Pasal ini oleh karena yang diancam hukuman itu perbuatan cabul dari orang dewasa terhadap orang belum dewasa.

5. Supaya dapat dihukum menurut Pasal ini, maka orang dewasa itu harus mengetaui atau setidak-tidaknya patut dapat menyangka bahwa temannya berbuat cabul itu belum dewasa. ${ }^{3}$

Pasal tersebut belum cukup mengakomodir seluruh perbuatan homoseksual. Pasal 292 KUHP masih terbatas mengatur mengenai seorang yang telah cukup umur yang melakukan perbuatan cabul atau hubungan seksual sesama jenis dengan sorang yang belum cukup umur saja, atau dengan kata lain KUHP yang berlaku saat ini hanya mengatur hubungan seksual sesama jenis yang telah dewasa terhadap anak-anak saja. Terhadap seorang yang telah dewasa melakukan perbuatan cabul atau melakukan hubungan seksual sesama jenis dengan seorang yang juga telah dewasa serta seorang yang masih belum cukup umur melakukan melakukan hubungan seksual sesama jenis dengan seseorang yang juga diketahui belum cukup umur belum terdapat pengaturan di dalam KUHP.

Perbuatan cabul atau hubungan seksual sesama jenis saat ini tidak terbatas hanya dilakukan oleh orang dewasa kepada anak-anak saja, tetapi juga dilakukan oleh orang dewasa dengan sesama orang dewasa, bahkan tidak menutup kemungkinan juga akan dilakukan oleh seorang anak yang belum cukup umur dengan sesama anak yang juga belum cukup umur. Sehingga dipandang perlu untuk dilakukan langkah-langkah nyata dalam hal perumusan aturan hukum yang mengakomodir seluruh pengaturan terhadap perbuatan cabul atau hubungan seksual sesama jenis yang dilakukan oleh komunitas LGBT yang telah sama-sama dewasa dan juga yang sama-sama masih berada dibawah umur.

Sehingga dapat disimpulkan bahwasanya LGBT merupakan bagian dari tindak pidana menurut hukum pidana Indonesia, yaitu diatur di dalam ketentuan Pasal 292 KUHP, akan tetapi ketentuan tersebut masih sangat terbatas hanya mengatur orang dewasa yang melakukan perbuatan cabul atau hubungan seksual sesama jenis dengan seorang anak di bawah umur saja.

Sebagai perbandingan, penulis memberikan Pasal dari negara yang melerang perbuatan homoseksual. Salah satu negara yang melarang adanya perbuatan tersebut adalah Guinea. LGBT menjadi perbuatan yang ilegal di Guinea. Pasal 325 KUHP Guinea mengkriminalkan aktivitas sesama jenis : Ayat(3): Serangan tidak senonoh Pasal 325 (Guinea) :

Siapa pun yang melakukan tindakan yang cabul atau bertentangan dengan alam dengan individu dari jenis kelamin yang sama akan dihukum 6 bulan - 3 tahun penjara

3 R.Soesilo, loc.cit. 
dan denda antara 100.000 - 1.000 .000 franc Guinea. Jika tindakan tersebut dilakukan dengan anak di bawah usia 21 tahun, hukuman maksimal akan ditegakkan. Jika tindakan ini dilakukan atau dilakukan dengan kekerasan, pihak yang bersalah akan dikenai hukuman penjara selama jangka waktu antara 5 dan 10 tahun.

Tindakan ini dilakukan Guinea karena tidak sesuai dengan kodrat manusia yang hidup berpasang-pasangan. Salah satu Negara ASEAN yang juga memberikan hukuman serta memasukkan perbuatan LGBT sebagai tindak pidana yang dapat dihukum adalah Singapura. Singapura dalam Pasal 377A KUHP melarang perbuatan tersebut. Bagian 377A dari KUHP Singapura adalah bagian utama dari undang-undang yang melarang hubungan seks antara orang dewasa yang saling menyetujui. Bagian 377A menyatakan Setiap laki-laki yang, di depan umum atau tertutup, melakukan, atau menjalankan perintah, atau mendapatkan atau mencoba untuk mendapatkan komisi oleh laki-laki manapun, setiap tindakan kasar terhadap orang lain, akan dihukum penjara untuk masa hukuman yang bisa berlanjut hingga 2 tahun.

\section{Kebijakan Hukum Pidana Mengenai Homoseksual}

laporan dari hasil Simposium Pembaharuan Hukum Pidana Nasional yang diselenggarakan pada Agustus 1980 di Semarang yang merekomendasikan bahwa untuk menetapkan kebijakan kriminalisasi perlu diperhatikan kriteria umum, yaitu apakah perbuatan itu tidak disukai atau dibenci oleh masyarakat karena merugikan, atau dapat merugikan, mendatangkan korban atau dapat mendatangkan korban. ${ }^{4}$ Data penolakan masyarakat yang bisa digunakan adalah survei yang dirilis oleh Pew Research Center yang mengemukakan data bahwa Indonesia sangat menolak homoseksualitas berdasarkan hasil survei yang menunjukan sekitar 93 persen mengatakan bahwa gay tidak seharusnya diterima. survei SMRC yang dilakukan pada Maret 2016, September dan Desember 2017 dengan jumlah responden 1.220 orang. Margin of error survei ini sebesar lebih kurang 3,1 persen sampai 3,2 persen. Berdasarkan survei tersebut hampir seluruh penduduk Indonesia menilai LGBT adalah ancaman. Sebanyak 87,6 persen berpendapat demikian, sementara 10,8 persen berpandangan sebaliknya, dan sisanya tidak menjawab. Hasil survei itu dapat dicermati sebagai bentuk reaksi penolakan masyarakat terhadap bentuk homoseksualitas termasuk perbuatan cabul yang dilakukan oleh pasangan sesama jenis.

Kemudian dalam untuk menetapkan kebijakan kriminalisasi perlu diperhatikan apakah biaya mengkriminalisasi seimbang dengan hasilnya yang akan dicapai, artinya cost pembuatan undang-undang, pengawasan dan penegakan hukum, serta beban yang dipikul pelaku kejahatan itu sendiri harus seimbang dengan situasi tertib hukum yang akan dicapai.

\subsection{Dasar Yuridis Kriminalisasi Perbuatan Homoseksual}

Undang-undang Nomor 11 Tahun 2012 tentang Pembentukan Peraturan Perundangundangan dalam Pasal 2 menyebutkan bahwa Pancasila sebagai segala sumber hukum negara. Pembentukan peraturan perundang- undangan termasuk dalam konteks Peraturan perundang-undangan yang memuat ketentuan pidana, bisa

4 Salman Luthan, Asas Dan Kriteria Kriminalisasi, Jurnal Hukum, Vol. 16, No. 1, 2009, HIm. 11-12. 
kita maknai sebagai pembentukan norma baru maupun perbaikan norma yang telah ada. Diperlukannya suatu aturan atau norma baru apabila kekosongan norma. Seperti yang telah dikemukakan di awal pada bagian latar belakang, permasalah hukum dalam penelitian ini adalah adanya kekosongan norma. Permasalahan tersebut adalah tidak adanya norma hukum pidana yang mengatur secara tegas ancaman pidana bagi perbuatan cabul yang dilakukan oleh pasangan sesama jenis yang subjek hukumnya sama-sama dewasa. Sementara kenyataan hukum, perbuatan yang demikian ada di masyarakat dan perbutaan itu mengganggu keseimbangan hukum.

Pembentukan norma baru dalam hukum pidana itu bisa dimaknai sebagai salah satu upaya kriminalisasi. Kriminalisasi yang bisa dimaknai sebagai suatu sarana dalam hukum untuk membuat suatu perbuatan yang sebelumnya bukan merupakan perbuatan pidana menjadi perbuatan pidanam guna mengendalikan kejahatan. Dalam hal ini Herbert L. Packer menyebutkan bahwa upaya penggendalian kejahatan yang dimaknai sebagai perbuatan anti sosial melalui penjatuhan pidana kepada orang yang melanggar peraturan pidana adalah satu dimensi hukum penting dalam masalah atau problem sosial. Usaha pengendalian perbuatan anti sosial dengan mengenakan pidana pada seseorang yang bersalah melanggar peraturan pidana, merupakan suatu problem sosial yang mempunyai dimensi hukum penting. ${ }^{5}$

Rumusan Pasal 292 KUHP tersebut dalam bentuk normatif dapat diuraikan ke dalam unsur subjektif dan unsur objektif. Unsur Subjektif tersebut adalah yang ia ketahui atau sepantasnya harus dapat ia duga. Sementara unsur objektif paling tidak ada empat unsur. Pertama, seorang dewasa. Kedua, melakukan tindakan melanggar kesusilaan, seorang anak belum dewasa dari jenis kelamin yang sama. Keempat, kebelumdewasaan. Rumusan Pasal ini menegaskan ancaman pidana bagi orang yang melakukan perbuatan cabul terhadap orang dengan jenis kelamin yang sama dan korbannya adalah seorang anak atau paling tidak diduganya korbannya itu belum dewasa. Sehingga ancaman pidana dalam rumusan Pasal 292 tersebut tidak berlaku bagi seseorang yang melakukan perbuatan cabul dengan jenis kelamin yang sama dan sama-sama sudah dewasa. Tidak dapat diancamkan pidana tersebut juga tidak lepas dari asas legalitas yang berlaku dalam hukum pidana. Asas yang dituangkan dalam ketentuan Pasal 1 Ayat (1) KUHP mengharuskan adanya ketentuan pidana yang telah menyatakan bahwa suatu perbuatan dilarang oleh norma hukum pidana.

\subsection{Dasar Teoritis Kriminalisasi Perbuatan Homoseksual}

Respon oleh negara atas suatu perbuatan yang dinilai jahat diartikan sebagai institusionalisasi kejahatan. Kejahatan yang telah diinstitusionalisasikan oleh negara itu bisa disebut sebagai Mala in Probihita, yakni perbuatan yang tidak dengan sendirinya dipandang buruk, akan tetapi karena hukum mendefinisikannya sebagai pelanggaran atau kejahatan. Sementara ada pula kejahatan yang belum diinstitusionalisasikan oleh negara melalui suatu instrumen hukum. Hal demikian bisa di artikan sebagai Mala in Se atau oleh Frank E. Hagan dalam Pengantar Kriminologi diartikannya sebagai perbuatan yang buruk dengan sendirinya, perilaku terlarang yang didasarkan kesepakatan atau konsensus luas tentang tata atau norma kelakuan bagi

\footnotetext{
5 Teguh Prasetyo, Kriminalisasi dalam Hukum Pidana, Nusa Media, Bandung, 2011, hlm. 25-26
} 
satu laranganPerbutan cabul yang dilakukan oleh pasangan sesama jenis kelamin dalam pandangan konsensus tata norma kelakuan di Indonesia adalah perbuatan yang dianggap sebagai perbuatan tercela. Namun tentu ukuran konsensus tata norma kelakuan itu tidak bisa sepenuhnya digunakan untuk menormakan perbutan tersebut ke dalam norma hukum. pada teori kriminalisasi, teori hukum alam, teori hukum positivisme, dan teori HAM.

Teori krimiminalisasi yang berbasis pada teori moral yang dikemukakan oleh Lord Devlin. Teori ini menyatakan bahwa kriminalisasi berpangkal tolak dari pendapat bahwa perbuatan yang harus dipandang sebagai kriminalitas adalah setiap perbuatan yang bersifat merusak atau tindak susila. Hal ini karena moralitas umum (common Morality) memiliki peranan esesensial untuk mempertahankan masyarakat. Jika ikatanikatan moral yang mengikat masyarakat hilang, masyarakat akan mengalami disintegrasi.

Selanjutya dalam prespektif teori paternalisme yang merupakan reaksi terhadap dari dasar kriminalisasi yang tidak dapat memberikan perlindungan kepada kelompokkelompok masyarakat yang memiliki kelemahan fisik, pikiran, dan mental seperti anak-anak dan pengguna narkoba. Tugas pokok teori ini adalah perlindungan untuk tidak merugikan diri sendiri. Hukum pidana melegitimasi pelarangan perbuatan seseorang yang dapat merugikan dirinya sendiri.

Hal demikian sejalan dengan apa yang dikemukakan oleh Henry Campbell mengenai bagaimanna sistem hukum alam itu lahir yakni ia lahir dengan prinsipprinsip yang dimaksudkan sebagai pedoman bagi sikap tindak manusia, yang bersifat independen dari peraturan hukum positif atau aturan hukum lainnya yang sedang berlaku di suatu negara, sistem hukum alam tersebut didapatkan oleh pemikiran rasional dari manusia yang tumbuh dan berkembang sesuai dengan hakikat perkembangan manusia yang benar, yaitu perkembangan mental, moral, dan hukumhukum fisika. Hakikat perkembangan manusia yang benar tersebut tidak dapat dikalahkan atau dikesampingkan oleh ketidakjujuran, kepura-puraan, dan hal-hal yang negatif lainnya. ${ }^{6}$

Pandangan yang bisa menegaskan itu adalah pandangan dari William Seal Carpenter juga mengemukakan tiga pengertian terkait hukum alam: Pertama, hukum alam sebagai kaidah moral yang merupakan tata cara penafsiran benar terhadap hukum positif. Kedua, hukum alam sebagai perangkat ketentuan alami yang berkedudukan lebih tinggi dari hukum buatan manusia (human law). Dan ketiga, ia mengemukakan pengertian yang mengartikan hukum alam sebagai sebagiannya tergantung di awang-awang, tetapi sebagiannya lagi ada ada hak-hak manusia. ${ }^{7}$

Mengenai teori positivisme yang mengenyampingkan materi muatan nilai moral itu bisa kita cermati dari gagasan yang dikemukakan oleh Hart yang menyebutkan arti dari positivisme sebagai berikut:

6 Munir Fuady, Teori-teori Besar (Grand Theory) dalam Hukum, Kencana, Jakarta, 2013, hlm. 17. 7 Ibid. 
a. Hukum adalah perintah.

b. Menempatkan penghargaan utama pada analisis konsep-konsep hukum, sehingga berbeda dari studi sosiologis dan historis serta berbeda pula dengan studi kritis.

c. Menempatkan rasionalitas keputusan-keputusan melalui pem-bentukan pemahaman secara logis terhadap peraturan-peraturan yang telah ada, tanpa perlu memperhatikan tujuan-tujuan sosial, kebijakan dan moralitas.

d. Mengenyampingkan sisi moral dengan dasar pertimbangan penghukuman berdasar pada ukuran moral tidak dapat ditegakan dan dipertahankan melalui penerapan logika rasional, pembuktian atau pengujian.

e. Memaknai hukum hanya sebagai hukum yang diundangkan, ditetapkan, positum, dan harus benar-benar dipisahkan dengan hukum yang semestinya diciptakan atau diinginkan. ${ }^{8}$

Pandangan oleh Hart itu ditegaskan oleh Jhon Austin seorang ahli hukum dari Inggris yang memaknai sumber hukum dalam prespektif postivisme hanyalah kekuasaan yang tertinggi dalam suatu negara. Artinya keberlakuan hukum tidak bisa dikaitkan dengan nilai moral atau ideal hukum melainkan tergantung pada kekuasaan tertinggi dalam suatu negara. ${ }^{9}$

Selain permasalahan moral dan hukum tersebut, permasalahan kriminalisasi perbuatan cabul yang dilakukan oleh pasangan sesama jenis kelamin dinilai sebagai permasalahan hak asasi manusia. Karena perbuatan cabul yang dilakukan dengan sesama jenis yang telah memiliki usia dewasa adalah pilihan yang dibangun dengan secara sadar dan tidak merugikan orang lain. Pandangan demikian tentu bisa dipahami sebagai bagian dari keinginan dipenuhinya HAM. Bentuk HAM dimaksud dalam hal itu adalah HAM yang dibangun dengan pendekatan natural right. Sebagaimana teori yang dikemukakan oleh Todung Mulya Lubis, terkait teori hak alami (natural rights) yang berpandangan bahwa HAM adalah hak yang dimiliki oleh seluruh manusia pada segala waktu dan tempat berdasarkan takdirnya sebagai manusia (human rights are rights that belong to all times and in all places by virtue of being born as human beings). ${ }^{10}$ Atau pandangan universal absolut yang memaknai HAM sebagai bagian yang memiliki nilai-nilai universal, karenannya ia tidak mempertimbangkan identitas sosial budaya yang terdapat pada masing-masing bangsa. ${ }^{11}$

Hal berlawanan bisa dibangun dengan pendekatan teori HAM yang lain, yakni teori positivis, yang berpandangan bahwa karena hak harus tertuang dalam hukum riil, maka pandangan sebagai hak melalui adanya jaminan konstitusi (right, then should be created and granted by constitution, laws and contracts). Pandangan ini secara nyata berasal dari ungkapan Bentham yang mengatakan bahwa, rights is a child of law, from

Satjipto Rahardjo, Ilmu Hukum, Citra Aditya Bakti, Bandung, 2006, hlm. 273 - 274.

Ibid., hlm. 274.

10 Majda El Muhtaj, Dimensi-dimensi HAM (Mengurai Hak Ekonomi, Sosial, dan Budaya), RajaGrafindo Persada, Jakarta, 2008, hlm. 2.

11 A. Masyhur Effendi, Perkembangan Dimensi Hak Asasi Manusia dan Proses Dinamika Penyusunan Hukum Hak Asasi Manusia, Ghalia Indonesia, Bogor, 2005, hlm. 78 - 79. 
real laws com real rights, but from imaginar law, laws of nature, come imaginary rights. Natural rights is simple nonsens, natural and imprecicible rights rethorical nonsens, nonsens upon still. ${ }^{12}$

Selain teori HAM positivis itu juga perlu diperhatikan teori relativis kultural (cultur relativist theory) yang mengemukakan bahwa menganggap hak itu bersifat universal merupakan pelanggaran satu dimensi terhadap dimensi kultural yang lain, atau disebut dengan imperialisme kultural (cultural imperialism). Yang ditekankan dalam teori ini adalah bahwa manusia merupakan interaksi sosial dan kultural serta perbedaan tradisi budaya dan peradaban berisikan perbedaan cara pandang kemanusiaan (differnt ways of being human). Oleh karenanya, penganut teori ini mengatakan, that rights belonging to all human beings at all times in all places would be the rights of desocialized and deculturized beings. ${ }^{13}$

Hal serupa teori kultural relativis itu bisa kita temui pada pandangan HAM sebagai partikularitas relatif, pandangan ini tidak hanya memaknai masalah HAM sebagai permasalahan universal namun juga sebagai permasalahan nasional masingmasing bangsa. Dalam pandangan ini, ketentuan atau dokumen-dokumen internasional harus diselaraskan, diserasikan, dan diseimbangkan serta memperoleh dukungan budaya bangsa. Dengan demikian HAM menjelma dalam suatu bangsa dengan adaptif, karena tidak hanya menjadikan pandangan khusus pada masing masing bangsa untuk bersikap defensif melainkan juga mencoba aktif mencari formulasi terhadap karakteristik HAM yang dianutnya. ${ }^{14}$

Berdasarkan teori kultural relativis dan pandangan partikularitas relatif maka perbuatan cabul yang dilakukan oleh pasangan sesama jenis tidak bisa dipandang sebagai permasalahan nilai HAM yang universal, melainkan permasalah nilai budaya bangsa. Dalam konteks ke-Indonesiaan aktivitas homoseksual dipandang sebagai perbuatan yang tidak sejalan dengan nilai budaya atau jiwa bangsa, karena itu transplantasi nilai HAM tidak bisa dilepaskan dari nilai budaya bangsa tersebut. Ukuran nilai budaya atau jiwa bangsa itu salah satunya bisa diukur dari Pancasila maka dapat dikatakan aktivitas homoseksual termasuk didalamnya perbuatan cabul yang dilakukan oleh pasangan sesama jenis kelamin itu tidak sejalan dengan nilainilai pancasila sebagaimana dijelaskan sebelumya.

2.3 Dasar Sosiologis Kriminalisasi Perbuatan cabul oleh Pasangan Sesama Jenis Kelamin

Von Savigny mengemukakan gagasan bahwa manusia di dunia ini terdiri atas berbagai bangsa dan tiap-tiap bangsa itu mempunyai jiwa bangsa sendiri yang disebut sebagai volkgeist, jiwa bangsa ini anatara satu bangsa dengan bangsa yang lain berbeda baik didasarkan pada waktu dan tempat. Semangat atau jiwa bangsa itu terjelma dalam bahasa, adat istiadat dan organisasi sosial. Jiwa bangsa itu tidak statis selalu berubahubah menurut keadaan masyarakat pada zaman ke zaman.

\footnotetext{
Majda El Muhtaj, Op.cit., hlm. 2.

Majda El Muhtaj, Ibid.

A. Masyhur Effendi, Op.cit., hlm. $79-80$.
} 
Perbuatan cabul yang dilakukan oleh pasangan sesama jenis tentu bisa dinilai sebagai suatu perbuatan yang tidak sejalan dengan jiwa bangsa. Karena perbuatan ini membuat nilai yang terkandung dalam Pancasila terkesampingkan. Utamanya nilai dalam sila pertama sebagaimana telah dijelaskan sebelumnya. Perbuatan demikian akan mengaburkan nilai yang menjadi semangat pembangunan hukum nasional. Reaksi masyarakat ini menunjukan apakah secara sosiologis ada ketidaksepakatan untuk menerima atau justru kesepakatan untuk menolak. Data penolakan masyarakat yang bisa digunakan adalah survei yang dirilis oleh Pew Research Center yang mengemukakan data bahwa Indonesia sangat menolak homoseksualitas berdasarkan hasil survei yang menunjukan sekitar 93 persen mengatakan bahwa gay tidak seharusnya diterima. Hasil survei itu dapat dicermati sebagai bentuk reaksi penolakan masyarakat terhadap bentuk homoseksualitas termasuk perbuatan cabul yang dilakukan oleh pasangan sesama jenis.

Guna memberikan legitimasi secara hukum terhadap proses penanganan aktivitas homoseksual, utamannya perbuatan cabul yang dilakukan oleh pasangan sesama jenis agar tidak melahirkan konflik yang berujung pada kekerasan di masyarakat adalah dengan menggunakan sarana hukum pidana. Pembuatan norma atau formulasi norma baru dalam hukum pidana yang mengatur mengenai larangan perbuatan cabul yang dilakukan oleh pasangan sesama jenis kelamin dapat dipahami sebagai upaya rasional yang bisa dilakukan guna menghindarkan konflik di masyarakat yang bisa berujung pada kekerasan.

Selain itu jiwa bangsa dalam konteks ke-Indonesiaan juga dapat dicermati dari hukum adat. Hukum adat yang didasari oleh semangat adat atau kebiasaan masyarakat yang kemudian dilengkapi dengan sanksi. ${ }^{15}$ Salah satu corak hukum adat adalah religio magis atau perilaku hukum atau kaidah-kaidah hukumnya berkaitan dengan kepercayaan terhadap yang ghaib dan untuk berdasarkan ajaran ke-Tuhanan Yang Maha Esa. ${ }^{16}$ Corak hukum adat yang demikianlah yang menjadi semangat masyarakat Indonesia dalam berperilaku hukum. Karenanya wajar dalam konteks sosiologis jika terjadi penolakan dari masyarakat terhadap aktivitas homoseksual termasuk perbutan cabul yang dilakukan oleh pasangan sesama jenis.

\section{SIMPULAN}

Hubungan seksual sesama jenis yang dilakukan oleh LGBT merupakan bagian dari tindak pidana menurut hukum pidana Indonesia, yaitu diatur di dalam ketentuan Pasal 292 KUHP, akan tetapi ketentuan tersebut masih sangat terbatas hanya mengatur orang dewasa yang melakukan perbuatan cabul atau berhubungan seks sesama jenis dengan seorang anak di bawah umur saja.

Perbuatan homoseksual perlu dijadikan sebagai tindak pidana di Indonesia dapat didasarkan pada tiga hal medasar, yakni dasar yuridis, teoritis, dan sosiologis. Pertama: dasar yuridis, memberikan landasan bagi pembentukan peraturan Perundangundangan, termasuk di dalamnya pembentukan norma hukum pidana,

\footnotetext{
15 Tolib Setiady, Intisari Hukum Adat Indonesia, Alfabeta, Bandung, 2009, hlm. 8. 16 Ibid
} 
selanjutnya sila pertama dalam Pancasila yang diamanatkan oleh pembentuk Undangundang sebagai sumber dari segala sumber hukum negara. Kedua: dasar teoritis, bisa didasarkan bahwa kriminalisasi perbuatan homoseksual telah memenuhi kriteria umum kriminalisasi yang didukung oleh bentuk teori kriminalisasi; teori moral, teori feinberg, dan teori paternalism, teori hukum alam, teori HAM positivis, teori HAM relativis kultural, ditambah pandangan HAM partikularitas relatif. Selanjutnya terkait ketiga: dasar sosiologis, bahwa perbuatan cabul yang dilakukan oleh pasangan sesama jenis tentu bisa dinilai sebagai suatu perbuatan yang tidak sejalan dengan jiwa bangsa, reaksi masyarakat yang melakukan penolakan terhadap aktivitas homoseksual, yang bisa didasarkan pada survei terkait hal tersebut, corak masyarakat hukum adat yang tergambar dalam corak hukum adat yang religiomagis menutup bagi masuknya aktivitas homoseksual.

\section{DAFTAR PUSTAKA}

\section{Dokumen Hukum}

Kitab Undang-Undang Hukum Pidana.

Republik Indonesia, Undang-Undang Tentang Hak Asasi Manusia.UU Nomor 39 Tahun1999.LN Tahun 1999 Nomor 3886, TLNRI Nomor 3889.

Republik Indonesia, Undang-Undang .Tentang Pornografi UU Nomor 44 Tahun 2008.

LN Tahun 2008 Nomor 181, TLNRI Nomor 4928Republik Indonesia, Undang-

\section{Buku} Undang Tentang Hukum Acara Pidana. UU Nomor 8 Tahun 1981.

Arif, Barda Nawawi. Beberapa Aspek Kebijakan Hukum Penegakan dan Pengembangan Hukum Pidana, Citra Aditya Bakti, Bandung, 1998.

Arif, Barda Nawawi. Bunga Rampai Kebijakan Hukum Pidana, Citra Aditya Bakti, Bandung, 2008

Arif, Barda Nawawi. Kebijakan Legislatif : Dalam Penanggulangan Kejahatan Dengan Pidana Penjara, Undip, Semarang, 2000.

Chazawi, Adami. Pelajaran Hukum Pidana Bagian I, Raja Grafindo, Jakarta, 2002.

Diantha, I Made Pasek. Metodologi Penelitian Hukum Normatif Dalam Justifikasi Teori Hukum, Prenada Media Group, Jakarta, 2017.

Fuady, Munir. Teori-teori Besar (Grand Theory) dalam Hukum, Kencana, Jakarta, 2013.

Hamzah, Andi. Hukum Pidana Indonesia, Sinar Grafika, Jakarta, 2017.

Hawari, Dadang. Pendekatan Psikoreligi Pada Homoseksual, FKUI, Jakarta, 2009.

Kartonegoro. Diktat Kuliah Hukum Pidana, Balai Lektur Mahasiswa, Jakarta, 2010.

Lamintang, P.A.F. Pidana Indonesia, Citra Aditya Bakti, Jakarta, 1997. 
Lamintang dan Franciscus Theojunior Lamintang, Dasar-Dasar Hukum Pidana Di Indonesia, Sinar Grafika, Jakarta, 2014.

Masyhur, A. Effendi. Perkembangan Dimensi Hak Asasi Manusia dan Proses Dinamika Penyusunan Hukum Hak Asasi Manusia, Ghalia Indonesia, Bogor, 2005.

Marpaung, Laden. KejahatanTerhadap Kesusilaan, Sinar Grafika, Jakarta,2004.

Muhtaj, Majda El. Dimensi-dimensi HAM (Mengurai Hak Ekonomi, Sosial, dan Budaya), RajaGrafindo Persada, Jakarta, 2008.

Moeljatno. Asas-Asas Hukum Pidana, Rineka Cipta, Jakarta, 2009.

Mulia, Musdah. Mengupas seksualitas, Opus Press, Jakarta, 2015.

Marzuki, Peter Mahmud. Penelitian Hukum, Kencana, Jakarta, 2017.

Nasution, Bahder Johan. Metode Penelitian Hukum, Mandar Maju, Bandung, 2008.

Prasetyo, Teguh. Kriminalisasi dalam Hukum Pidana, Nusa Media, Bandung, 2011.

Rahayu. Hukum Hak Asasi Manusia, Badan Penerbit Universitas Diponegoro, Semarang, 2010.

Rahardjo, Satjipto. Ilmu Hukum, Citra Aditya Bakti, Bandung, 2006.

Sahetapy, J.E., Bunga Rampai Viktimisasi, Eresco, Bandung, . 1995.

Soesilo, R. Kitab Undang-Undang Hukum Pidana (KUHP) Serta KomentarKomentarnya Lengkap PasalDemi Pasal, Politeia, Bogor, 2010.

Soerjono, Soekanto dan Sri Mamudji. Penelitian Hukum Normatif, Raja Grafindo Persada, Jakarta, 2015.

Sudarto. Hukum dan Hukum Pidana, Alumni, Bandung, 2007.

Sudarto. Hukum Pidana dan Perkembangan Masyarakat, Sinar Baru, Bandung, 1983.

Setiady, Tolib. Intisari Hukum Adat Indonesia, Alfabeta, Bandung, 2009.Hamzah Ahmad dan Anando Santoso, Kamus Pintar Bahasa Indonesia, Fajar Mulia, Surabaya, 1996.

Wijayanto, Roni. Asas-Asas Hukum Pidana Indonesia, Mandar Maju, Bandung, 2012.

\section{Jurnal:}

Fatimah, Asyari . "LGBT dan Hukum Positif Indonesia", Jurnal legalitas, Vol. 2, No. 2, 2017. http://ejurnal.untag-smd.ac.id/index.php/LG/article/view/3385 
Muhammad, Rustamaji. "Biomijuridika: Pemikiran Ilmu Hukum Pidana Berketuhanan dari Barda Nawawi Arief", Jurnal Hukum, Vol. 2 No.1, 2019. https://ujh.unja.ac.id/index.php/home/article/view/65

Salman, Luthan. Asas Dan Kriteria Kriminalisasi, Jurnal Hukum, Vol. 16, No. 1, 2009. https://www.neliti.com/publications/84197/asas-dan-kriteria-kriminalisasi

Soponyono, Eko. "Kebijakan Kriminalisasi Kumpul Kebo Dalam Pembangunan Hukum Pidana Indonesia, Jurnal Masalah-Masalah Hukum", Vol.1, No. 2, 2013. https://ejournal.undip.ac.id/index.php/mmh/article/view/5807

Susilowati,Christina Maya Indah. "Pancasila Sebagai Sumber Segala Sumber Hukum Dan Kekerasan Atas Nama Agama Di Indonesia", Jurnal Masalah-Masalah hukum, Vol.1, No.1, 2016. https://ejournal.undip.ac.id/index.php/mmh/article/view/13677

Tongat. Pancasila Sebagai Dasar Falsafah Negara dan Makna Filosofinya Dalam Pembaharuan Hukum Pidana Nasional, Jurnal Masalah-Masalah Hukum, Vol 1 , No 1 , 2012. https://ejournal.undip.ac.id/index.php/mmh/article/view/5770

Widya, Ramailis Neri. "Homoseksual Potret Perilaku Seksual Menyimpang Dalam Perspektif Kriminalogi", Islam dan Budaya Melayu, Jurnal Hukum Vol. 1, No. 2, 2015, hlm.

5. http;//journal.uir.ac.id/index.php/sisilainrealita/article/download/2455/14 $21 /$ 